\title{
The Heron-Allen \& Earland Type Slide Collection of Foraminifera in the British Museum (Natural History)
}

\author{
R. L. HODGKINSON \\ Department of Palaeontology, British Museum (Natural History), Cromwell Road, \\ London SW7 5BD
}

\begin{abstract}
Heron-Allen \& Earland collaborated on the study of the Foraminifera over a period of 25 years. During this partnership they amassed a large faunal reference collection (The Type Slide Collection) which was presented to the British Museum (Natural History) between 1926 and 1943. An introductory biography of Edward Heron-Allen and Arthur Earland shows that they came from very different backgrounds and had very different capabilities, but were united by a mutual interest in foraminifera; their dedication made them the foremost British foraminiferologists of the time. The appearance and content of the collection are described with background information on how these slides were prepared. Heron-Allen \& Earland's own method of curation, using a series of detailed indices (Keys), is also explained. The history of the Type Slide Collection, including its transfer from Selsey to the Museum to save it from destruction, is recounted and its importance, as a national collection, assessed.
\end{abstract}

\section{INTRODUCTION}

The Type Slide Collection comprises faunal reference slides, mostly Recent and some fossil, on which the taxonomic descriptions of Heron-Allen \& Earland were based. It was presented to the British Museum (Natural History) (BMNH) between 1926 and 1943 by Heron-Allen. Since, however, Earland was intimately concerned with much of its preparation, the Collection is here referred to under their joint names. There are 874 faunal slides (the numbers usually prefixed by the letters TS), accompanied by a series of binders, each containing a loose-leaf Key to part of the Collection, together with a card index. When describing new species or varieties Heron-A.llen \& Earland did not select types in the modern sense, but based their descriptions on suites of specimens from different localities; these specimens are housed in the Collection. When they did select specimens for illustration, these are, for the most part, mounted individually and stored separately and do not form part of the Type Slide Collection sensu stricto. All are housed in the Micropalaeontology Section, Department of Palaeontology, BMNH.

This article contains a short background history on the presentation of these slides to the BMNH, which as a collection of Recent foraminifera alone, is second only in size and importance to the Challenger Collection of H.B. Brady. It is also offered as a tribute to the association of the two noted English foraminiferal workers, Edward Heron-Allen and Arthur Earland.

The word "type", as used in the Heron-Allen \& Earland Type Slide Collection, it must be noted, is not used in the modern strict sense, but as in many reference collections of that time, implies that the specimens were, in the eyes of the authors, "typical" of the species. That being said, because so few lectotypes and paralectotypes have subsequently been erected by revisers, the Collection remains an untapped depository of syntypes of the many species and varieties described as new by Heron-Allen and Earland during their quarter-century partnership. It is accompanied by detailed Keys to the slides, listing genera, species and varieties and with the detailed locality information, gives us a valuable insight into their understanding of the species concept and of their curatorial methods. The Collection, furthermore, contains the only faunal record to the important publications of Heron-Allen \& Earland and of Earland concerning the Southern Ocean and Antarctica (Discovery and Terra Nova reports), East Africa (Kerimba Achipelago) and British waters (Clare Island Survey, Goldseeker Cruise, Plymouth District).

The collection contains a wealth of material, picked and beautifully arranged. Recently, the Trochamminacea from the Southern Ocean and Antarctica have been re-examined by Brönnimann \& Whittaker (1988). This is just the beginning. Much more awaits examination and revision by the dedicated specialist. It is hoped that this article will stimulate such interest.

\section{HISTORICAL BACKGROUND}

The first intimation that Heron-Allen had presented a large collection to the Trustees of the British Museum (Natural History) was contained in a paper by Kirkpatrick (1927) entitled the "Heron-Allen Collection of Foraminifera". He makes brief reference, however, to the gift totalling over 17,000 slides, containing in excess of four million specimens and which included the 874 Type Slides, but about which there was unfortunately nothing more than a cursory mention.

To understand the history of the Type Slide Collection it is first necessary to examine the record of each man and the way in which their partnership evolved and remained constant for 25 years.

\section{Edward Heron-Allen}

Heron-Allen was born on December 17th 1861. He was well educated and was admitted Solicitor of the Supreme 
Court in 1884, retiring from practice at the age of 50. From boyhood he had been interested in foraminifera, stimulated by his Science Master at school to examine a foraminiferous sand and by Geikie's Geology Primer (1873) with its illustration of foraminifera. In 1894 he produced his Prolegomena towards the study of Chalk foraminifera notable for its information on simple processing and preparation techniques, so sadly lacking in the literature before that time.

He was an able scholar, showing a willingness and ability to read French, German and Persian. He was already a Fellow of both the Linnean and Royal Microscopical societies and counted Charles Elcock as a friend. In August 1892 he had made the acquaintance of William Fortescue Millett. It was through the encouragement of Elcock and Millett and also of Frederick Chapman that his interest in the Foraminifera grew. Even in 1894 he recognised the difficulty of identifying and naming specimens, this he believed being due to their "dimorphism' and 'intermediate forms'.

It was not until 1908 that he published his next paper, which was written with $\mathrm{Mr}$ A. Earland. During the quiescent period between 1894 and 1908, Heron-Allen had continued to collect fossil and Recent Foraminifera, especially from the Selsey area and has also settled into a newly built house, "Large Acres" (now unfortunately pulled down), at Selsey, Sussex in 1906 just 5 years before his retirement from the Firm of Solicitors in London.

The outcome of all this collecting, especially in the Selsey area, was an attempt to involve Millett in a publication. Millett, however, was not in the best of health at the time and was also uncertain of the merit of this investigation, so he advised Heron-Allen to contact another experienced foraminiferologist, Arthur Earland, who had lately produced a paper on the Foraminifera of the Bognor shore sand (Earland, 1905), an area in which Heron-Allen was also interested. It was this approach to Earland by letter in 1907, that paved the way for the quarter century of collaboration. Their joint association produced 38 papers and at least 200 new species and varieties of foraminifera. Further information on the many faceted career of Heron-Allen can be obtained from obituaries by Earland (1943), Gregory (1943) and in Who Was Who 1941-1950 (edited by Adam \& Charles Black, 1952). Fig. 1 reproduces a portrait of Heron-Allen made when he was in his sixties.

\section{Arthur Earland}

Earland was born on 3rd November 1866. Receiving only a formal education he entered the Post Office Savings Bank Department of the Civil Service at the age of 19, rising to be its Assistant Controller by his retirement in 1926.

Hedley's (1958) obituary tells us much about his early life. Evidently he had declined a university education. In about 1887, on his own volition, he had become interested in objects as seen under the microscope and his interest perhaps encouraged him, in 1891, to join the Quekett Microscopical Club, there to meet others of like mind. It was here he met his mentor Edward Halkyard (whose manuscript on the Blue Marl of Biarritz was to be edited for posthumous publication by Heron-Allen \& Earland in 1919) and it was he who encouraged Earland to study the Foraminifera. The dates of this meeting varies between sources. The Quekett obituary (Morley-Jones, 1958) says he joined the Club in 1891 and then met Halkyard (Hedley, 1958), but in the introduction by the editors of the Blue Marl paper, they say he met Halkyard at the Royal Microscopical Socjety between 1885 and 1888. Whatever the truth of the matter, Halkyard had a most important role in channelling his initial interest. Earland reciprocated in aiding $\mathrm{Halky}$ ard by collecting Recent foraminifera from Jersey (Halkyard, 1919:v). About the time that he joined the Quekett, he published his first paper on foraminifera (from Malta; Earland \& Cook, 1891), so it would seem that he had begun to study foraminifera before this date. He proceeded to produce papers at regular intervals until 1957, a year before his death.

In 1908 he published his first paper with Edward HeronAllen, a person he found to be an untiring enthusiast, a man of boundless energy and a charming host. A letter addressed to Cameron Ovey in the files of the Micropalaeontology Section, Department of Palaeontology, British Museum (Natural History) gives a rare insight into the working of this partnership. He, Earland, provided identifications, described new species, supervised artists and made up the plates. Heron-Allen provided the money, assembled manuscripts, proof-read and arranged specimens. When compiling the Type Slide Collection they worked together at the same table, Earland calling out the names and positions on the slide, Heron-Allen writing the information in the Keys (indices). Although they both picked and sorted, Earland admitted himself, that he disliked "spade work".

In 1933 the partnership ceased, partly because of HeronAllen's illness and other personal problems. Earland, having vainly tried to make Heron-Allen reconsider his decision not to finish the Antarctic study (Discovery Reports) with him, was left to complete parts 2-4 (Earland, 1933, 1934, 1936) alone. Communication may not have entirely ceased as Earland seemed to be aware of the work being done by his erstwhile colleague.

The obituaries (MacFayden, 1959; Hedley, 1958; MorelyJones, 1958) record Earland as a painstaking and accurate worker with little interest in foraminiferal classification and a detestation of the Rules of Nomenclature. He had an eye for detail and in interest in ccology. A fall hastened his death at the age of 91 in 1958. breaking the remaining link with the Brady era.

A photograph of Earland taken when he was 60 is reproduced in Fig. 2.

\section{THE TYPE SLIDE COLLECTION}

\section{Date of presentation of the Collection}

In a copy of part of his Will (dated 19th October 1915), Heron-Allen made his wishes clearly known to the British Museum (Natural History). He left all his books, microscopes, apparatus, specimens and materials of every kind connected with the Foraminifera to Arthur Earland during his lifetime and, after Earland's death, to the Museum. Earland could make them over to the Museum at any time. Why he made a Will in favour of the Museum is never stated, but he was on good terms with Dr Harmer, the then Keeper 

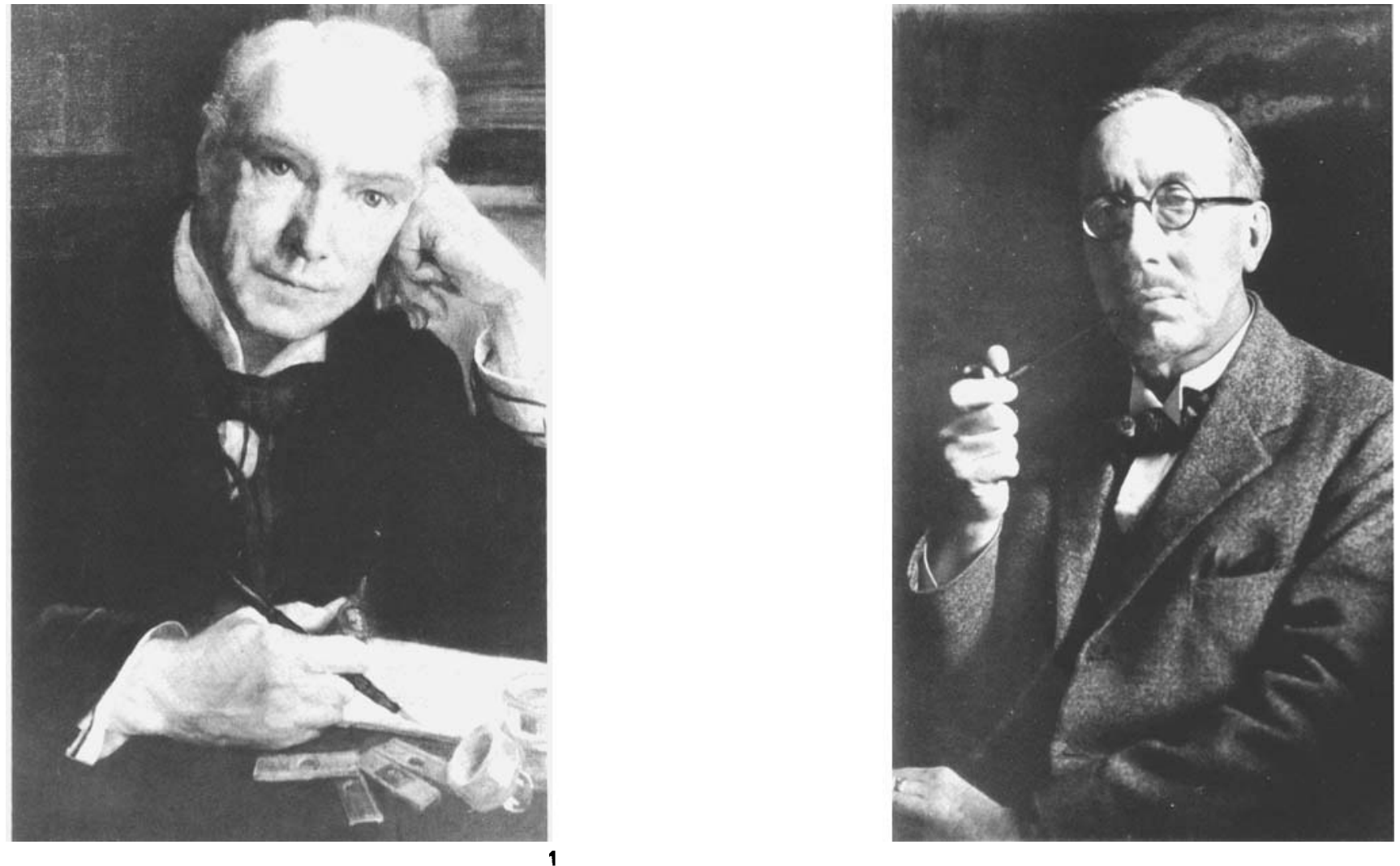

Fig. 1 Painting by Hardman, captioned "Edward Heron-Allen. F.R.S., 1928"

Fig. 2 Photograph entitled "Arthur Earland F.R.M.S., 1926".

Both from prints in the Micropalaeontology Section, British Museum (Nat. Hist.)

of Zoology, and was at the time engaged in studying the samples taken by the Terra Nora Expedition with which Harmer was involved.

In 1925, Heron-Allen wrote to Harmer in some distress. Apparently the conditions at his house in Selsey were not ideal for the storage either of books (because of Blue Mould infestation in his library) or specimens (because of the high humidity caused by the sea fogs). He asked for permission of the Trustees to temporarily house his collection at the Museum for up to a year, which at his own risk, they agreed to do, placing them in the Murray Oceanographic Room. In November 1926 Heron-Allen presented his collection to the Museum and the Trustees accepted it in December of the same year. Heron-Allen asked, and this was agreed, that he should be allowed to rearrange and remove certain specimens for study when necessary. His final Will, on his death in 1943, confirmed this Gift, but no mention of Earland's rights (contained in the Will of 1915 ) is repeated. At no time are the contents of the Gift itemised.

\section{Contents of the Collection}

At the time of his $1926 \mathrm{Gift}$ the items were not specified. However, during a written dispute about the accommodation for this Collection, in November 1931, a list was prepared by Heron-Allen of all his material housed in the Museum, which, since some of the dates mentioned were post-1926. must have been brought in subsequent to the original Gift and would be covered in his final Will of 1943.
The following Type Slides, with the dates referring to the publications of Heron-Allen \& Earland, were all probably presented in 1926. (There are some discrepancies from Heron-Allen's list as noted in parentheses).
Selsey Bill 1908-1911

North Sca 1912-1917

Clare Island 1913

North Sea 1913

Kerimba Archipelago

$1914 \& 1915$

South Cornwall 1916

West Scotland 1916
Thurammina 1919 (North Sea 1917) Biarritz Bluc Marl 1919

Terra Nova 1922

Nigeria 1922

Corsicat 1923 (1922)

lord Howe lsland 1924

Filter Quarry, Moorabool 1914
The following Type Slides, with dates referring to the publications of the Heron-Allen \& Earland, were probably presented post-1926.

South Allantic 1929-1930

Antarctic (Discolery)

Plymouth 1930

1932 (and in progress at the time HeronAllen's letter was writlent.

He claimed that there were in total over 800 Type Slides, each containing up to 120 species, and they were all catalogued and indexed (both in the form of Keys and card indexes).

\section{Nature of the Slide Preparations}

The collection is numbered up to and including TS 795, although additional suffixes bring the total number of slides 
to 874 . The cavity slides contain, for the most part, faunal associations. A few carry type and figured specimens only (e.g. TS 625 A-C). Some contain examples of one genus (e.g. Thurammina from the North Sea - TS 258). The slides themselves, of which a selection is shown in Plate 1 , normally measure $3 \times 1$ inches $(76 \times 25 \mathrm{~mm})$ and were professionally made, some of the later ones by Flatters \& Gamet of Manchester, but none bear a maker's name except for some of the earliest which are marked "Charles Elcock, Belfast" and later ones "J.D. Siddall", which were probably gifts.

The backgrounds are black (e.g. TS 40), sometimes are exposed photographic paper which is now browning (e.g. TS 62 ), or often black paper or card on which white lines are printed or etched (e.g. TS 143). Most squares are numbered. The black card may be overlaid with white paper punched to show this black background (e.g. TS 579).

The frame is of cardboard (usually) or wood (very rarely). The glass cover is held in position by a paper sheath. The background had been variously treated with lacquer, gum arabic diluted with glycerine (Elcock slides), or photographic paper washed with human saliva before applying gum (see Heron-Allen, 1894). Others have unvarnished albumen paper, which Earland liked, or gelatin of which he disapproved because the specimens tended to sink into it, making them difficult to study.

The labels were individually printed for each major publication, some being made for Heron-Allen by Suttley \& Siverlock of Blackfriars, London.

Where the number of species on a faunal slide exceeds the number of squares available they were doubled up, but similar genera or species were normally kept separate.

\section{Curation of the Collection}

A. The indices (Keys) to the Collection. Not only did Heron-Allen \& Earland prepare faunal slides but they made comprehensive indices (Keys) (see Plate 2). These comprise the content of 11 loose-leaf Walker Transfer Cases of various sizes (Size T 71/2; T731/2; T74 $\frac{1}{2}$ and T 8 ), made by John Walker \& Co., Faringdon House, Warwick Lane, London. The information is all handwritten in ink, in almost all cases in the hand of Heron-Allen (Pl. 2, Figs. 1-4). Each have been photocopied for everyday use, but unfortunately these copies have not lasted so well as the original pen and ink. It is hoped that this information will shortly be transferred to tape or disc storage.

Heron-Allen \& Earland prepared these Keys with great care. There are usually two parts to the Key: the index to genera and species, and the index to the slide contents.

i. The Index of Genera and Species

These are alphabetically arranged and are followed by a sequence of numbers. For example, Psammosphaera fusca, Type Slide 131 , cell 26 , is normally written $131 / 26$. Sometimes where there is a continuous sequence it is abbreviated even more, the first number of the Type Slide usually being omitted (i.e. 31/26). This information is usually found in the front of the Key.

ii. Index to the Contents of the Slide

This is found under the TS number in the body of the Key. This shows the cell/square number, the genus and species or variety and sometimes indicates the proportion of specimens in the sample (i.e. $\mathrm{R}=$ rare, $\mathrm{VR}=$ very rare, $\mathrm{F}=$ frequent, $\mathrm{C}=$ common, $\mathrm{VC}=$ very common; these appear to be purely arbitrary estimations). Sometimes the number of specimens is given if very rare (e.g. one).

In most cases the author of the species and/or variety is given but it is usually abbreviated, e.g. Lagena marginalis W \& B (= Walker \& Boys) var. irregularis Sidebottom. Often a comment is added after a specific or varietal name (e.g. "trigonal" or "monstrous" or "worn" or "worn and dead", "one large fragment", etc.). To save unnecessary writing they often give abbreviated details of the locality under the Type Slide heading. The user of the Key is referred back to the opening pages of the Key where there is often some sort of introduction, with Lists of Stations and Haul Numbers set against locality details, e.g. Goldseeker Haul 22 = Noss Head, Moray Firth, N xW $1 / 2$ W 3', 43 fathoms.

B. List of Indices (Keys). The names of the Keys given below are as they appear on the title page or binder spine. The word 'binder' refers to a Walker Transfer Case.

Key to Type Slides $1 / 477$ (in binder)

Key to North Sea Foraminifera dredged by the Fisheries Cruiser Goldseeker, Type Slides 131-172 (not in binder); also Type Slides of Saccammina sphaerica and Psammosphaera fusca

Key to Clare Island Survey, Type Slides 77-109, also 125 and 126 (in binder)

Key to Kerimba Archipelago, Type Slides 173-208 (in binder)

Key to "Runa", Type Slides 209-241 (in binder)

Key to 'Terra Nova' Expedition, Type Slides 269-353 (in binder)

Key to 'Discovery' Investigations (Part 1, Falkland Islands Area), Type Slides 478-525 (in binder)

Key to 'Discovery' Investigations Part 2, South Georgia Area), Type Slides 525A-609 (in binder)

Key to 'Discovery' Investigations (Part 3, Antarctic), Type Slides 627-740 (in binder)

Key to Miscellaneous Type Slides 611-623 and 742-759 (in binder)

Key to British Recent Foraminifera (in binder)

Key to Foraminifera of the Plymouth District, Type Slides 399 and 400 and 469-477 (in envelope)

Key to the "Terra Nova" Foraminifera, Type Slides 624626 (in envelope)

Key to Lord Howe Island South Pacific, Type Slide 373 (in envelope)

Index of Type Slides, numerically and geographically arranged (in binder within an envelope).

C. The Card Index. This is alphabetically arranged by

\section{Explanation of Plate 1}

Examples of some of the Heron-Allen \& Earland Type Slides. TS 719E is the most common type; TS 408 was specially designed like TS 480A, and is much wider than usual. TS 402 has most of the information written on the slide masked by the sheath.

All natural size. 


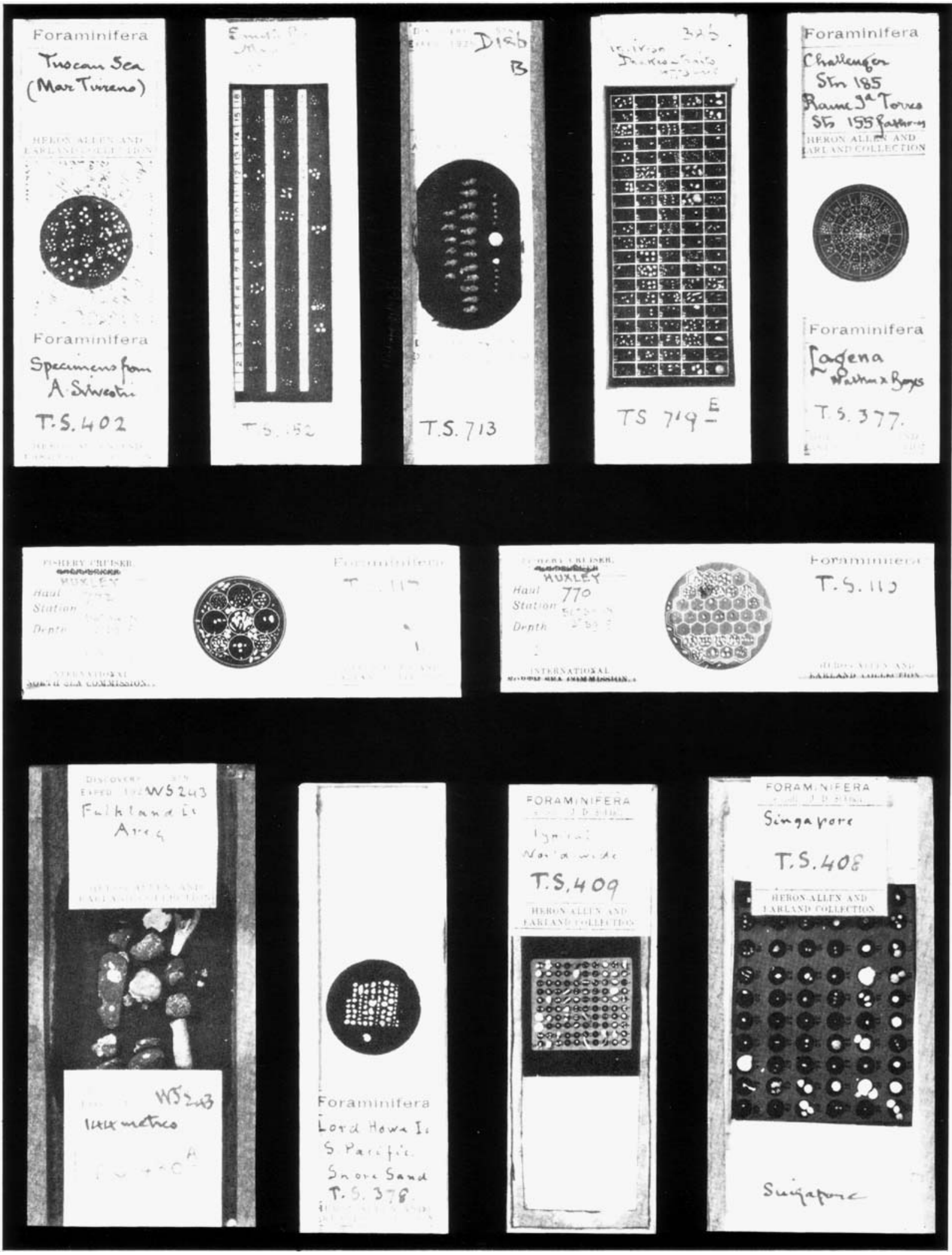


genera and species. The "black ink entries" are genera and species recorded by Heron-Allen \& Earland, while the "red ink entries" are the genera and species discussed in notes to other genera and species. This index contains only a basic reference to the publication with page number (e.g. Bognor 216). It may indicate that the species is figured but gives no details.

\section{SUMMARY}

The Heron-Allen \& Earland Type Slide Collection provides a magnificent example of a late Victorian-early 20 th Century foraminiferal collection; the slides themselves and the labelling are works of art, the faunas are beautifully and painstakingly arranged and catalogued. To the specialist, it allows each fauna to be viewed in its entirety and provides an indexed pool of specimens, especially syntypes, for the elucidation of phenotypic variation and for further studies. This is particularly important for syntypes knowing that they were selected by the author/s of the species in question and thus coming within the confines of their species concept.

However, such a collection has its disadvantages. The slides must be handled with great care to prevent displacement of specimens, especially the larger rounded forms. Information covered by the paper sheath can only be seen when the sheath is removed; this involves opening the slides and putting the specimens at risk. The paper sheaths themselves, over half a century old, are showing signs of wear, and need constant repair. Finally the Keys need careful storage, handling and conservation.

It is hoped that this article will serve to publicise this important collection. However, because of its nature it is not suitable for loan. Interested bona fide foraminiferal workers, visiting the Museum, are nevertheless encouraged to consult it and where the need may arise, to borrow and photograph individual specimens if they can be easily isolated from the faunal slides.

\section{ACKNOWLEDGEMENTS}

My thanks to Dr J. E. Whittaker for advice and assistance throughout, to Professor F.T. Banner for critically reading the manuscript, and to the Museum's photographers for reproduction of Plates 1-2 and Figs. 1-2.

\section{Manuscript received February 1988 \\ Revised Manuscript accepted May 1989.}

\section{REFERENCES}

Black, A \& C (editors) 1952. Heron-Allen Who Was Who 1941-1950,532-533 A \& C Black, London.
Brönnimann,P.\& Whittaker, J.E. 1988. The Trochamminacea of the Discovery Reports Areview' of the Trochamminacea (Protozoa: Foraminiferida) described from South Atlantic and Antarctic waters by Heron-Allen \& Earland (1932) and Earland (1933; 1934; 1936) British Museum (Natural History, London, viii + 152 pp., Figs 1-52.

Earland, A. 1905. The foraminifera of the shore-sand at Bognor, Sussex. J. Quekett microsc. Club. London, ser. 2, 19, 187-232, pls. 11-14.

Earland, A. 1933, Foraminifera; Part 2, South Georgia 'Discovery' Rep., Cambridge, 7, 27-136, pls. 1-7.

Earland, A. 1934. Foraminifera; Part 3, The Falkland Sector of the Antarctic (excluding South Georgia). 'Discovery' Rep., Cambridge, 10, 1-208, pls. 1-10.

Earland, A. 1936. Additional records from the Weddell Sea sector from material obtained by the S.Y. Scotia. 'Discovery' Rep., Cambridge, 13, 1-76, pls. 1-2, 2 A.

Earland, A. 1943. Edward Heron-Allen, F.R.S. $J / R$. microsc. Soc., London, 63, 48-50.

Earland, A. \& Cooke, J.H. 1891. Notes on the Recent Foraminifera of Malta. Mediterranean nat., Malta, 1, 5759.

Geikie, A. 1873. Geology (Science Primers), First Edition, viii + 135 pp. Macmillan \& Co., London.

Gregory, R.A. 1943. Edward Heron-Allen. Obit. Not. Fell. R. Soc. Lond., 12 (4), 447-454.

Halkyard, E. 1919. The Fossil Foraminifera of the Blue Marl of the Cote des Basques, Biarritz (Edited with additions by E. Heron-Allen and A. Earland). Mem. Proc. Machr. Lit. Phil. Soc'., 62, xxiv + 145 pp., pls. 1-9.

Hedley, R.H. 1958. Mr Arthur Earland. Nature, London, 181, 1440-1441

Heron-Allen, E. 1894. Prolegomena towards the study of Chalk foraminifera. An elementary paper on the collection, preparation, examination, identification and mounting of foraminifera from the Chalk, illustrated by a study of the Chalk from the Twyford-Maidenhead Railway cutting. 36 pp. H.S. Nichols \& Co., London.

Heron-Allen, E. \& Earland, A. 1908. On Cucloloculina, a new generic type of Foraminifera. With a preliminary study of the foraminiferous deposits and shore-sands of Selsey Bill. Il R. microsc. Soc., London 1908, 529-543, pl. 12.

Heron-Allen, E. \& Earland, A. 1909. On the Recent and fossil Foraminifera of the shore-sands at Selsey Bill, Sussex - 2. JIR. microsc. Soc., London, 1909, 306-336, pls. $15,16$.

Heron-Allen, E. \& Earland, A. 1909. On the Recent and

\section{Explanation of Plate 2}

The Keys to the Heron-Allen \& Earland Type Slide Collection.

Fig. I Frontispiece to one of the Keys.

Fig. 2 Part of an Index to genera and species.

Fig. 3 Initial portion of a page from the Index to a Type Slide (TS 627A).

Fig. 4 The only authenticated handwriting of A. Earland yet found in the Keys.

Fig. 5 Part of the initial portion of a Key, giving additional information on Haul numbers not given in the Index under the TS number. Note the "ghosting" due to the acidity of the ink. 
The Heron-Allen \& Earland Type Slide Collection of Foraminifera

"DISCOVERY INVESTLGATLONS. Ammotaculites

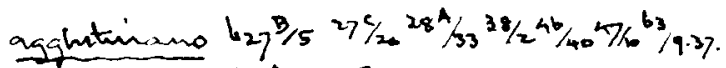

$77 / 3696 / 1897 / 427.94 / 3196 / 3125 / 233 / 1434 / 3239 / 440 / 2$

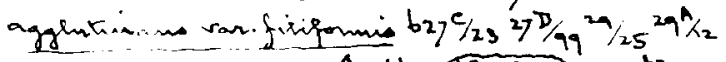

$298 / 16296 / 339 / 16^{43 / 27} 454 / 346 / 37 h^{48 / 16^{51 / 9}} 47 / 43$ b3/37

$97 / 42701 / 2319 E / 3122 / 1825 / 221 / 2 ; \quad 28 / 1933 / 7,35 / 4039 / 24401 / 8$

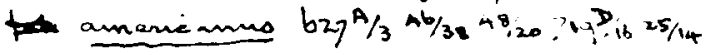

$26 / 2334 / 4538 / 44$

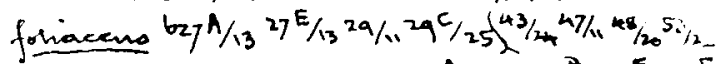

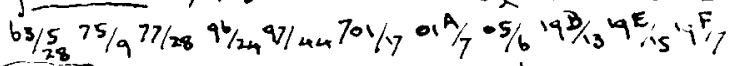

$26 / 23 \sqrt{2 a} / 1525 / 2430 / 1931 / 10^{32 / 32} 33 / 70^{35 / 39} 36 / 49^{37} 39 / 22$

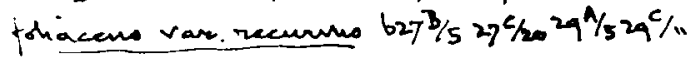

$47 / 163 / 536 \quad 733 / 7 \cdot 36 / 40 \quad 39 / 20 \quad 4 \%$

tenuimange $629^{C} / 1779^{A / 33}$

A minnocabieides

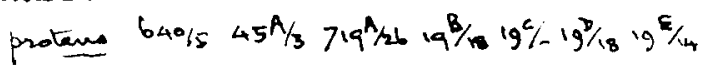

2
NB. The Texc- he AtEarland alcone.

WS $555 \quad$ TS b2 $7^{A}$

Fation MS55S Heddalsca 385, uetron 3 1 A mandacena clavata

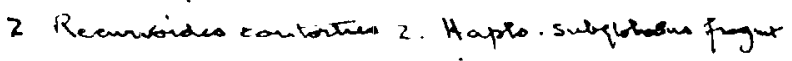
Eyclamemina sabienearis !

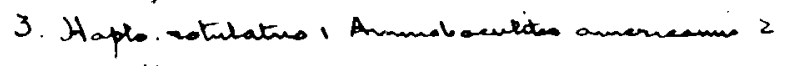

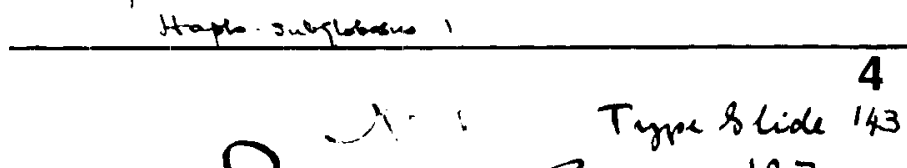

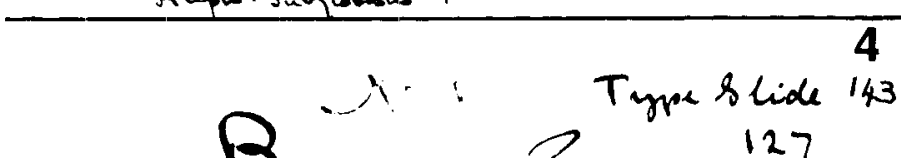

Bognor. Sunex 127

Shovesand collected betwaecen Boguor caes Jeepham

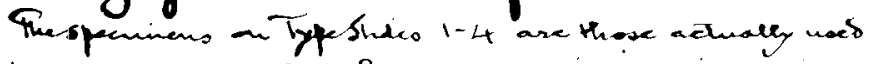
in the preparation of my Bogerer fapen wive idcuxificationo as

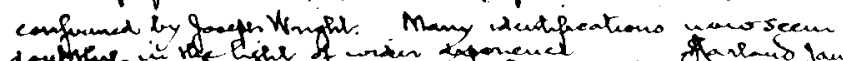

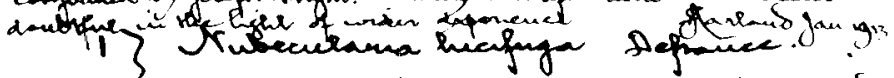

$2\}$ Atomedanx, wetldevedpeb t vancts.

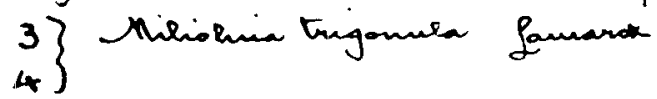

$$
\begin{aligned}
& \text { Have } 1=\text { Station Z } K A_{3} \\
& \begin{array}{llcc}
.2 & 4 & k B 3 \\
.24 & \quad 4 C_{4}
\end{array}
\end{aligned}
$$

Key to Jtane Nos.

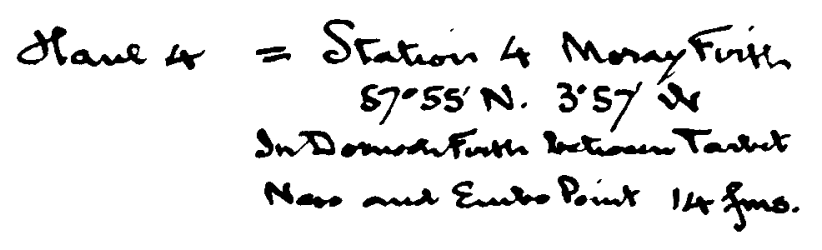

$$
\text { vol iii p.ugg }
$$

Hanl 5 Sutors of Cromanty Nrww2

$\mathrm{FC}_{3}$

Sol i. p. 16

155 
fossil Foraminifera of the shore-sands of Selsey Bill, Sussex - 3.JlR. microsc. Soc., London, 422-446, 1909 , pls. 17-18.

Heron-Allen, E. \& Earland, A. 1909. On the Recent and Fossil Foraminifera of the shore-sands of Selsey Bill, Sussex - 4. Jl R. microsc. Soc., London, 1909, 677-698, pls. 20-21.

Heron-Allen, E. \& Earland, A. 1910. On the Recent and fossil Foraminifera of the shore-sands of Selsey Bill, Sussex -5 . The Cretaceous Foraminifera. J/R. microsc. Soc., London, 1910, 401-426, pls. 6-11

Heron-Allen, E \& Earland, A. 1910. On the Recent and fossil Foraminifera of the shore-sands of Selsey Bill, Sussex - 6 . A contribution towards the aetiology of Massilina secans (d'Orbigny sp.). IIR. miscrosc. Soc., London, 1910,693695.

Heron-Allen, E. \& Earland, A. 1911. On the Recent and fossil Foraminifera of the shore-sands of Selsey Bill, Sussex - 7. Supplement (Addenda et corrigenda). $/ l R$. microsc. Soc., London, 1911, 298-343, pls. 9-13.

Heron-Allen, E. \& Earland, A. 1911. On the Recent and fossil Foraminifera of the shore-sands of Selsey Bill, Sussex - 8. Tabular List of species and localities. // $R$. microsc. Soc., London, 1911, 436-448.

Heron-Allen, E. \& Earland, A. 1912. On some foraminifera from the North Sea, etc., dredged by the Fisheries Cruiser Goldseeker (International North Sea Investigations Scotland); Part 1 - On some New Astrorhizidae and shell structure. Jl R. microsc. Soc., London, 1912, 382-389, pls. 5-6.

Heron-Allen, E. \& Earland, A. 1912. On the distribution of Saccammina sphaerica (M. Sars) and Psammosphaera fusca (Schultze) in the North Sea; particularly with reference to the suggested identity of the two species. Rep. Br. Ass. Advmt Sci., London, 82, 498-499.

Heron-Allen, E. \& Earland, A. 1913. On some foraminifera from the North Sea, dredged by the Fisheries Cruiser Huxley (International North Sea Investigations - England). Il Quekettmicrosc. Club London, ser. 2, 12, 121-138, pls. 10-11.

Heron-Allen, E. \& Earland. A. 1913. On some Foraminifera from the North Sea, etc., dredged by the Fisheries Cruiser Goldseeker (International North Sea Investigations Scotland). Part 2 - On the distribution of Saccammina sphaerica (M.Sars) and Psammosphaera fusca (Schultze) in the North Sea: particularly with reference to the suggested identity of the two species. $J / R$. microsc. Soc'., London, 1913, 1-26, pls. 1-4.

Heron-Allen, E. \& Earland, A. 1913. On some foraminifera of the North Sea, etc., dredged by the Fisheries Cruiser Goldseeker (International North Sea Investigations Scotland). Part 3 - On Cornuspira diffusa, a new type from the North Sea. Jl R. microsc. Soc., London 1913, 272-276, pl 12.

Heron-Allen, E. \& Earland, A. 1913. Clare Island Survey: part 64 - Foraminifera Proc. R. Ir. Acad., Dublin, 31 (sect. 3), 1-188, pls. 1-13.

Heron-Allen, E. E \& Earland, A. 1914 1915. The Foraminifera of the Kerimba Archipelago (Portuguese East Africa); Part 1. Trans. zool. Soc. Lond., 20, 363-390, pls. 35-37 (1914); Part2. Ibid, 543-794, pls. 40-53 (1915).

Heron-Allen, E. \& Earland, A. 1916. The Foraminifera of the shore-sands, and shallow water zone of the south coast of Cornwall. $/ / R$. microsc. Soc., London, 1916, 29-55, pls. 5-9

Heron-Allen, E. \& Earland, A. 1916. The Foraminifera of the west of Scotland. Collected by Prof. W. Herdman, F.R.S., on the cruise of the S.Y. Runa July-Sept. 1913. Being a contribution to Spolia Runiana. Trans. Linn. Soc, Lond., ser. 2, Zool., 11, 197-299, pls. 39-43.

Heron-Allen, E. \& Earland, A. 1917. On some foraminifera from the North Sea, etc., dredged by the Fisheries Cruiser Goldseeker (International North Sea Investigations Scotland. Part 4 - on Nouria rugosa; a new species of foraminifera from the Faroe Channel. JlR. Microsc. Soc.. London, 1917, 361-364, pl. 23. Ibid ., part 5 - On Thurammina papillata Brady: a study in variation. $J / R$. microsc. Soc., London, 1917, 530-537, pls. 26-30.

Heron-Allen, E. \& Earland, A. 1922, Protozoa. Part 2. Foraminifera. Nat. Hist. Rep. Br. Antart. 'Terra Nova' Exped., London, (Zool.), 6, 25-268, pls. 1-8.

Heron-Allen, E. \& Earland, A. 1922. Les foraminifères des 'Sables Rouges' du Golfe d'Ajaccio (Cote nord). Bull. Soc. Sci. Hist. \& nat. Corse, Bastia, 109-149, pls. 1-2.

Heron-Allen, E \& Earland, A. 1922. Foraminifera of the Eocene clay of Nigeria.Bull.geol. Surv. Nigeria, London, 3, 138-148, pl.12

Heron-Allen, E. \& Earland, A. 1924. The Miocene foraminifera of the 'Filter Quarry', Moorabool River, Victoria, Australia. J/R. microsc. Soc., London, 121-186, pls 7-14.

Heron-Allen, E. \& Earland, A. 1924. The Foraminifera of Lord Howe Island, South Pacific. // Linn. Soc., London (Zoology), 35, 599-647, pls.35-37.

Heron-Allen, E. \& Earland, A. 1929. Some new foraminifera from the South Atlantic. Part 1 and Part 2. J/R. microsc. Soc., London, ser. 3, 49, 102-108, pls. 1-3 and 324-334, pls. $1-4$.

Heron-Allen, E \& Earland, A. 1930. The Foraminifera of the Plymouth district. Part 1 and Part 2. J/R. microsc. Soc., London, 50, 46-84, pls. 1-3 and 161-199, pls, 4-5.

Heron-Allen, E. \& Earland, A. 1930. Some new foraminifera from the South Atlantic. Part 3, Miliammina a new siliceous genus. $/ / R$. microsc. Soc., London, 30, 38-45, pl. 1 .

Heron-Allen, E. \& Earland, A. 1932. Some new foraminifera from the South Atlantic. Part 4. I/ R. microsc. Soc., London, Ser. 3, 52, 253-261, pls. 1-2.

Heron-Allen, E. \& Earland, A. 1932. Foraminifera; Part 1 The ice-free area of the Falkland Islands and adjacent seas. 'Discovery' Rep., Cambridge, 4, 291-459, pls. 6-17.

Kirkpatrick, R. 1927. Heron-Allen Collection of foraminifera. Nat. Hist. Mag., London, 1 (1), 27-30.

Macfayden, W.A. 1959. Arthur Earland. I/ R. microsc'. Soc.,London, 7 (3-4), 146-150.

Morley-Jones, A. 1958. Arthur Earland (1866-1958). Il Quekett microsc. Club, London, ser. 4, 5 (4), 109-110. 